\title{
Dynamic changes of rhizosphere soil bacterial community and nutrients in cadmium polluted soils with soybean-corn intercropping
}

Han Li', Luyun Luo ${ }^{2 *}$, Bin Tang ${ }^{1}$, Huanle Guo ${ }^{1 *}$, Zhongyang Cao ${ }^{1}$, Qiang Zeng ${ }^{1}$, Songlin Chen ${ }^{1}$ and Zhihui Chen ${ }^{1 *}$

\begin{abstract}
Background: Soybean-corn intercropping is widely practised by farmers in Southwest China. Although rhizosphere microorganisms are important in nutrient cycling processes, the differences in rhizosphere microbial communities between intercropped soybean and corn and their monoculture are poorly known. Additionally, the effects of cadmium (Cd) pollution on these differences have not been examined. Therefore, a field experiment was conducted in $\mathrm{Cd}$-polluted soil to determine the effects of monocultures and soybean-corn intercropping systems on Cd concentrations in plants, on rhizosphere bacterial communities, soil nutrients and $\mathrm{Cd}$ availability. Plants and soils were examined five times in the growing season, and Illumina sequencing of 16S rRNA genes was used to analyze the rhizosphere bacterial communities.
\end{abstract}

Results: Intercropping did not alter Cd concentrations in corn and soybean, but changed soil available Cd (ACd) concentrations and caused different effects in the rhizosphere soils of the two crop species. However, there was little difference in bacterial community diversity for the same crop species under the two planting modes. Proteobacteria, Chloroflexi, Acidobacteria, Actinobacteria and Firmicutes were the dominant phyla in the soybean and corn rhizospheres. In ecological networks of bacterial communities, intercropping soybean (IS) had more module hubs and connectors, whereas intercropped corn (IC) had fewer module hubs and connectors than those of corresponding monoculture crops. Soil organic matter (SOM) was the key factor affecting soybean rhizosphere bacterial communities, whereas available nutrients (N, P, K) were the key factors affecting those in corn rhizosphere. During the cropping season, the concentration of soil available phosphorus (AP) in the intercropped soybean-corn was significantly higher than that in corresponding monocultures. In addition, the soil available potassium (AK) concentration was higher in intercropped soybean than that in monocropped soybean.

Conclusions: Intercropped soybean-corn lead to an increase in the AP concentration during the growing season, and although crop absorption of Cd was not affected in the Cd-contaminated soil, soil ACd concentration was affected. Intercropped soybean-corn also affected the soil physicochemical properties and rhizosphere bacterial community structure. Thus, intercropped soybean-corn was a key factor in determining changes in microbial community composition and networks. These results provide a basic ecological framework for soil microbial function in Cd-contaminated soil.

\footnotetext{
*Correspondence: luoluyun1992@163.com; guole469@163.com; czhui2008@163.com

${ }^{1}$ Crop Research Institute, Hunan Academy of Agricultural Sciences,

Changsha, China

${ }^{2}$ Yangtze Normal University, Chongqing, China
}

(c) The Author(s) 2022. Open Access This article is licensed under a Creative Commons Attribution 4.0 International License, which permits use, sharing, adaptation, distribution and reproduction in any medium or format, as long as you give appropriate credit to the original author(s) and the source, provide a link to the Creative Commons licence, and indicate if changes were made. The images or other third party material in this article are included in the article's Creative Commons licence, unless indicated otherwise in a credit line to the material. If material is not included in the article's Creative Commons licence and your intended use is not permitted by statutory regulation or exceeds the permitted use, you will need to obtain permission directly from the copyright holder. To view a copy of this licence, visit http://creativecommons.org/licenses/by/4.0/. The Creative Commons Public Domain Dedication waiver (http://creativeco mmons.org/publicdomain/zero/1.0/) applies to the data made available in this article, unless otherwise stated in a credit line to the data. 
Keywords: Rhizosphere bacterial community, Monoculture, Intercropping, Soil available cadmium, Soil

physicochemical properties, a diversity, Phylogenetic molecular ecological network, Illumina sequencing

\section{Background}

Long-term application of phosphate fertilizers, pesticides, sewage irrigation and municipal waste has led to cadmium $(\mathrm{Cd})$ to becoming a major pollutant in agricultural soils $[1,2]$. Soil Cd pollution causes serious effect of agricultural safety and human health [3-5], because $\mathrm{Cd}$ is toxic to biological organisms [6]. Soil microorganisms have important roles in transforming soil organic matter and increasing soil nutrient availability and thus affect the growth, development, yield and quality of crops [7]. Microbes also affect soil nutrient supplies by producing various organic acids, hormones, antibiotics, alcohols, vitamins and other compounds $[8,9]$. Species, numbers and activities of soil microorganisms can be reliable biological indicators of soil nutrient conditions $[8,10]$. Therefore, it is urgent to understand the influencing factors of rhizosphere soil microorganisms in cadmium contaminated soil.

Intercropping is a high-efficiency planting pattern of planting in which two or more crop species are planted simultaneously in the same field [11, 12]. Appropriate intercropping can regulate absorption of $\mathrm{Cd}$ and other heavy metals; inhibit diseases, insects and weeds; promote efficient crop use of soil nutrients; improve crop yield and land use efficiency; and facilitate the development of sustainable agricultural production [13, 14]. Intercropping has become a new strategy for efficient and safe use of heavy metal-contaminated soils in recent years. It can moderate negative effects of heavy metals on soil microorganisms by regulating soil physicochemical properties, soil microbial diversity and plant root exudates $[15,16]$. For example, tree-herb intercropping can alleviate toxic effects of heavy metals on soil microbes and alter their composition in contaminated soils [17, 18]. Maize-tomato intercropping has been shown to reduce $\mathrm{pH}$ levels and urease activity, increases acid phosphatase activity, and changes root microorganism population structure in Cd contaminated soils [19].

Soybean-corn intercropping is widely practised by farmers in China. Previous studies on intercropping have focused primarily on crop yields, use of heat and light resources and nutrient uptake [20-23]. Although intercropping can affect soil bacterial community diversity and improve soil nutrient management [24], little is known about the interactions between plant heavy metal absorption by crops, soil properties, and soil bacterial communities in soybean-corn intercropping systems on metal(loid)-contaminated soils. Therefore, the aim of this study was to investigate changes in soil properties and bacterial communities in $\mathrm{Cd}$-contaminated soil under soybean-corn intercropping by sampling over time. The objectives were to determine whether different planting patterns affected soil properties and bacterial communities, and more importantly, whether changes in soil properties and bacterial communities moderated the negative effects of $\mathrm{Cd}$.

\section{Results}

Concentrations of available cadmium in the soil and cadmium in plant tissues

In the soybean monoculture, the available $\mathrm{Cd}$ (ACd) concentration in the rhizosphere soils decreased and then increased, with the lowest value occurring on day 40 . However, in intercropped soybean, the opposite trend was observed (Fig. 1a). The concentration of ACd was significantly $(P<0.05)$ different between intercropped and monoculture soybean rhizosphere soils at 40, 60, 80, and 100 days (Fig. 1a). The ACd concentration in the monocropped corn rhizosphere soil all decreased from day 20 and 60, then increased on day 60 and 80 , and finally decreased from day 80 to 100 , with the lowest value on day 40 . However, the opposite trend was observed in intercropped corn soil (Fig. 1c).

The dynamic changes of $\mathrm{Cd}$ concentration were similar in intercropped and monocropped soybean/corn plants throughout the crop planting season (Fig. 1b, d). $\mathrm{Cd}$ concentration in intercropped and monocropped soybean gradually increased from day 20 to 80 , reached the highest on day 80, and then decreased from day 80 to 100 (Fig. 1b). In intercropped and monocropped corn, Cd concentration gradually decreased from day 20 to 40, and then stabilized beginning on day 40 (Fig. 1d).

\section{Effects of soybean and corn intercropping on soil physicochemical properties}

Soil properties were measured in samples collected 20, 40, 60, 80, and 100 days after sowing (Fig. 2). Physicochemical properties were compared between monocropped and intercropped corn and soybean at each sample point (Fig. 2). Rhizosphere soil pH decreased in monocropped soybean, but increased in corn (Fig. 2a, b). In addition, rhizosphere soil $\mathrm{pH}$ in intercropped soybean and corn decreased first but then increased, with the lowest values occurring on day 60 (Fig. 2a, b). During the soybean season, the concentrations of available phosphorus (AP) and available potassium (AK) were significantly 

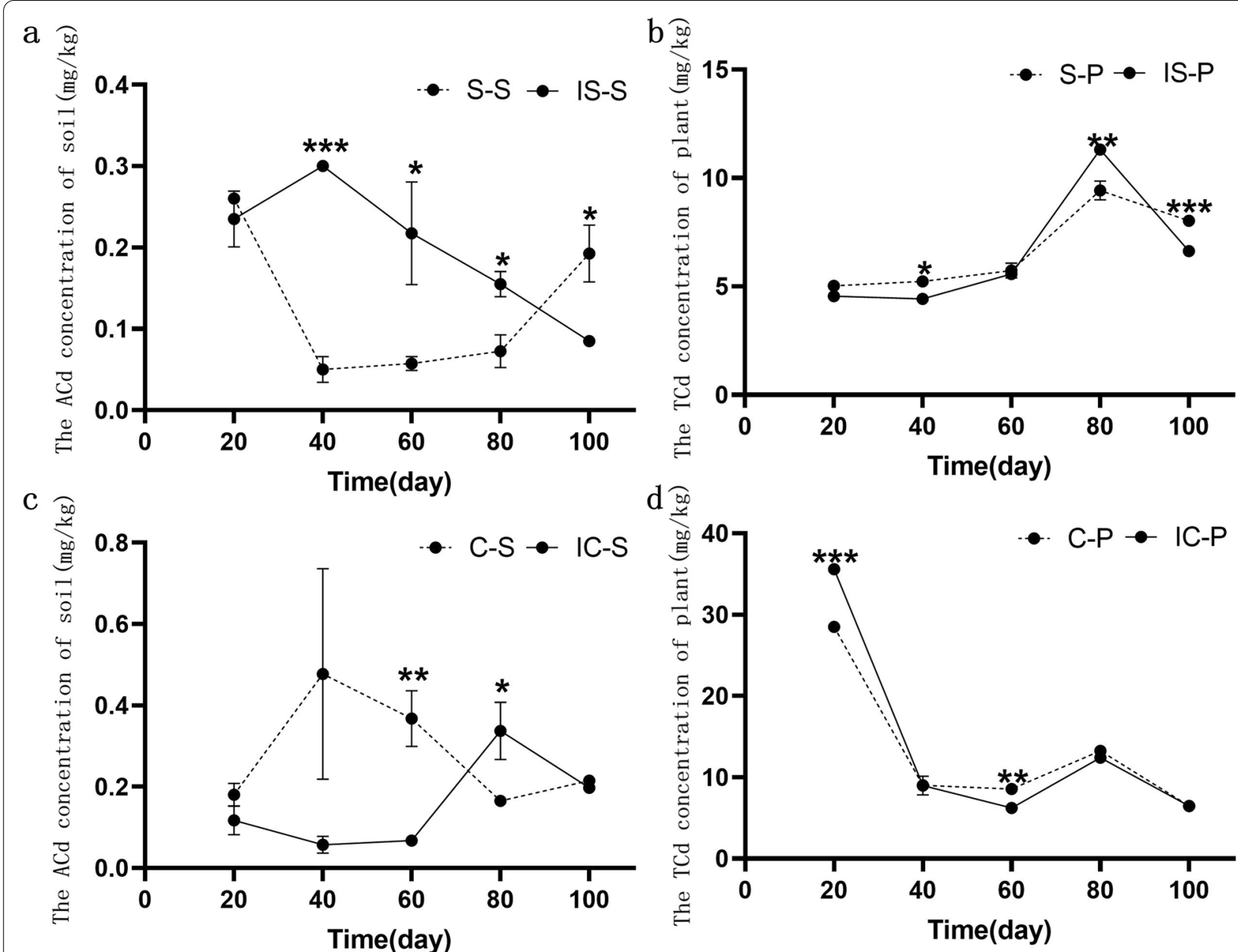

$\mathrm{d} \overparen{00}$

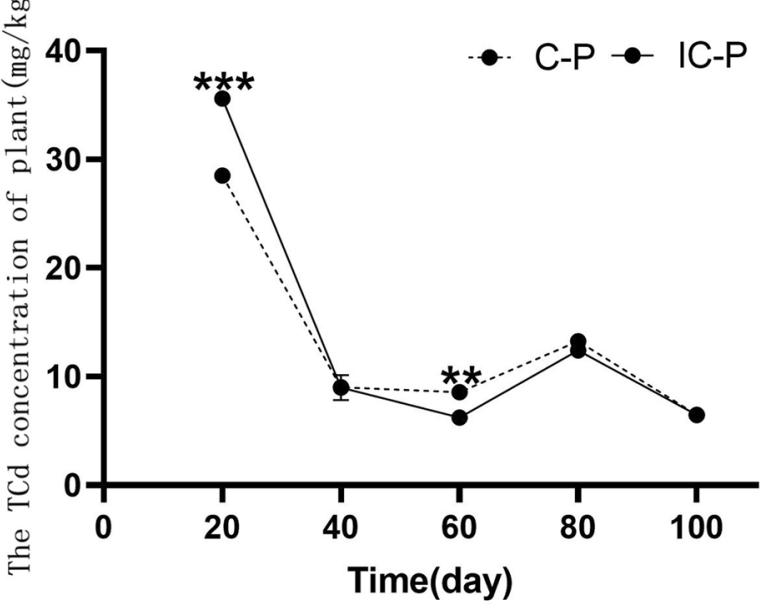

Fig. 1 The concentration of ACd of intercropping and monoculture crop soil and TCd of crop intercropping and monoculture crop at five time points. a ACd concentration of intercropping and monoculture soybean soil; b TCd concentration of intercropping and monoculture soybean plant; c ACd concentration of intercropping and monoculture corn soil; $\mathbf{d}$ TCd concentration of intercropping and monoculture corn plant. S-S: monoculture soybean soil, IS-S: intercropping soybean soil, C-S: monoculture corn soil, IC-S: intercropping corn soil, S-P: monoculture soybean plant, IS-P: intercropping soybean plant, C-P: monoculture corn plant, IC-P: intercropping corn plant

higher in intercropped soybean soil than in the monocropped soybean soil (Fig. 2e, i). During the corn season, the soil AP concentration was significantly higher in intercropped corn than in monocropped corn (Fig. 2f). The concentration of soil organic matter (SOM) of intercropping corn soil was lower in intercropped corn than in monocropped corn on day 20 , although it was higher at other times (Fig. 2d). The AK concentration was higher in intercropped corn soil than in monocropped corn soil on day 20, although it was lower than that at other time (Fig. 2j). The available nitrogen (AN) concentration was lower in intercropped corn than in the monocropped corn on day 100, although it was higher than that at other time points (Fig. 2h).

(See figure on next page.)

Fig. 2 The soil physicochemical properties of soybean and corn intercropping soil. a pH value of intercropping and monoculture soybean soil; $\mathbf{b}$ pH value of intercropping and monoculture corn soil; $\mathbf{c}$ SOM concentration of intercropping and monoculture soybean soil; $\mathbf{d}$ SOM concentration of intercropping and monoculture corn soil; e AP concentration of intercropping and monoculture soybean soil; f AP concentration of intercropping and monoculture corn soil; $\mathbf{g}$ AN concentration intercropping and monoculture soybean soil; $\mathbf{h}$ AN concentration of intercropping and monoculture corn soil; i AK concentration of intercropping and monoculture soybean soil; $\mathbf{j}$ AK concentration of intercropping and monoculture corn soil.S: monoculture soybean, IS: intercropping soybean, C: monoculture corn, IC: intercropping corn. SOM: soil organic matter, AP: available phosphorus, AN: available nitrogen, AK: available kalium 

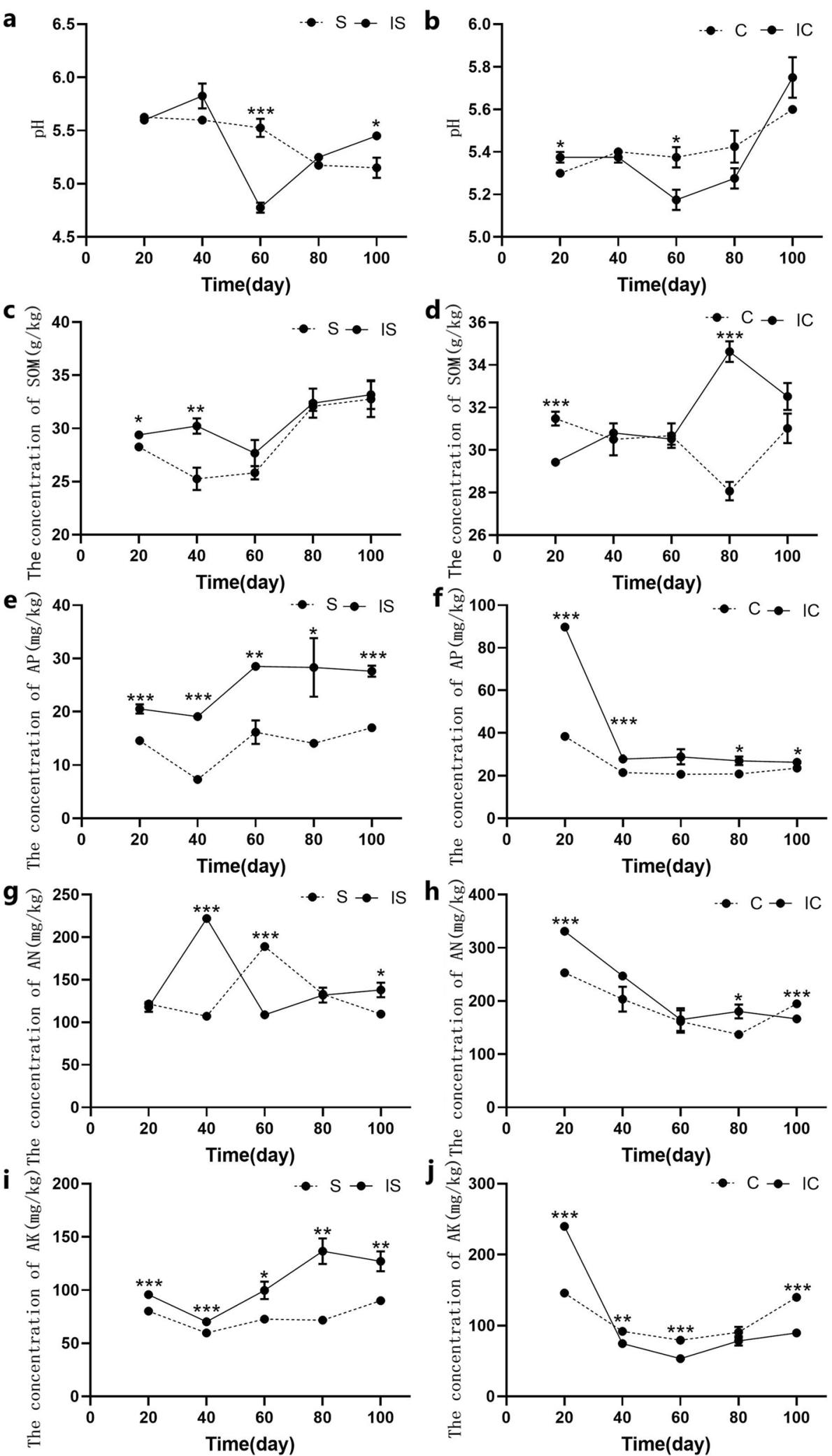

Fig. 2 (See legend on previous page.) 
Effects of soybean and corn intercropping on the $\alpha$ and $\beta$ diversity of bacterial communities in the crop rhizosphere soil

A total of 3,881,770 high-quality sequences were obtained from Illumina MiSeq sequencing of 80 rhizosphere soil samples. The observed richness operational taxonomic unit (OTU) numbers and Shannon and inverse Simpson indices decreased first but then increased with time in monoculture and intercropped soybean rhizosphere soil. In the monocropped and intercropped corn rhizosphere soils, there were no significant differences in richness and diversity at different times (Fig. 3a). The Chaol estimated richness of the monocropped and intercropped corn and soybean rhizosphere soil gradually increased through the five sampling time points (Fig. 3a). According to Student's $t$ test results, the $\alpha$ diversity indices were significantly different between the monocropped corn and soybean on days 40,60 and 80 as well as the intercropped corn and soybean on days 20,40 and 80 (Fig. 3a). Significant differences were also detected in $\alpha$ diversity indices between the monocropped and intercropping soybean on day 80 and between the monocropped and intercropped corn on day 40 day (Fig. 3a). The $\alpha$ diversity of intercropped/ monocropped corn was higher than that of intercropped/ monocropped soybean. In general, there was a little difference in bacterial community $\alpha$ diversity across rhizosphere soils of the same crop sampled at different times.

The principal coordinate analysis (PCoA) (Fig. 3b, c) and PERMANOVA results (Tables S1 and S2) showed that the rhizosphere bacterial community structure of monocropped soybean was significantly different from day 20 to 80 , whereas that of intercropped soybean was significantly different on day $20,40,60(80)$ and 100 . In the monocropped and intercropped corn, rhizosphere bacterial community structure was significantly different among the five stages $(P<0.05)$. Rhizosphere bacterial community structures was significantly different in the monocropped corn and soybean among five stages and in intercropped soybean and corn on days 20(40), 60, 80 and 100. In the monocropped and intercropped soybean, rhizosphere bacterial community structure was significantly different on days 20, 40 and 80 . In monoculture and intercropped corn, rhizosphere bacterial community structure was significantly different on day 40 and 60 .

\section{Molecular ecological networks of bacterial communities under different planting modes}

In our study, only a few microbes had many connections with others according to the phylogenetic molecular ecological network (pMENs) results (Figs. S1, S2). The group IS had the higher average connectivity (avgK:5.958) than S group. But the group IC had the lower average connectivity (avgK:2.2) than $\mathrm{C}$ group. The nodes and links for all four groups including S $(537,1380)$, IS $(574,1710), C(581,918)$, and IC $(500,550)$ were obtained in this study (Table 1$)$. The values of average clustering coefficient (avgCC), average geodesic distance (GD) and modularity of empirical networks were significantly higher than those of their corresponding random values with identical sizes in our study (Table 1). In our study, $1.82 \%$ of bacterial OTUs were module hubs and $1.14 \%$ of OTUs that were connectors. The group IS had the more module hubs and connectors than corresponding monoculture crop group did, while the group IC had the fewer module hubs and connectors (Tables S3, S4).

\section{Changes in bacterial taxa in rhizosphere soils at different times}

The soil bacterial communities changed significantly at different growth stages. The phyla Actinobacteria, Proteobacteria, Chloroflexi, Firmicutes, Acidobacteria and Bacteroidetes accounted for 88.02 and $96.38 \%$ of rhizosphere soil communities in soil samples (Fig. S3). The main phyla were displayed in Fig. 4. The relative abundance of Proteobacteria in intercropped soybean rhizosphere soil was significantly lower than that in the monocropped soybean rhizosphere soil at days 40 and 100, but was significantly higher on day 80 . The relative abundance of Proteobacteria in intercropped corn rhizosphere soil was significantly higher than that in the monocropped corn rhizosphere soil on days 40 and 100 . There were no significant differences in relative abundance of Actinobacteria, Chloroflexi and Acidoacteria between the intercropped and monocropped crop rhizosphere soils. However, a significant difference in the main phyla was observed between soybean and corn rhizosphere soil. The relative abundance of Bacteroidetes in intercropped corn rhizosphere soil was significantly higher at days 80 and 100, but the relative abundance of Firmicutes in the intercropped soybean rhizosphere soil was significantly lower on day 100. Compared with that of the other phyla, the abundance of Firmicutes was also lower in the intercropped corn than in the corresponding monocropped corn on day 40.

\section{Analysis of correlations analysis between bacterial communities and environmental factors}

The Pearson correlation analysis results showed that only SOM was positively correlated with bacterial community structure in the rhizospheres of intercropped and monocropped soybean $(P<0.01)$. However, there were no significant correlations between rhizosphere soil bacterial $\alpha$ diversity and physicochemical properties $(P>0.05)$ in the intercropped and monocropped corn (Table S5). 


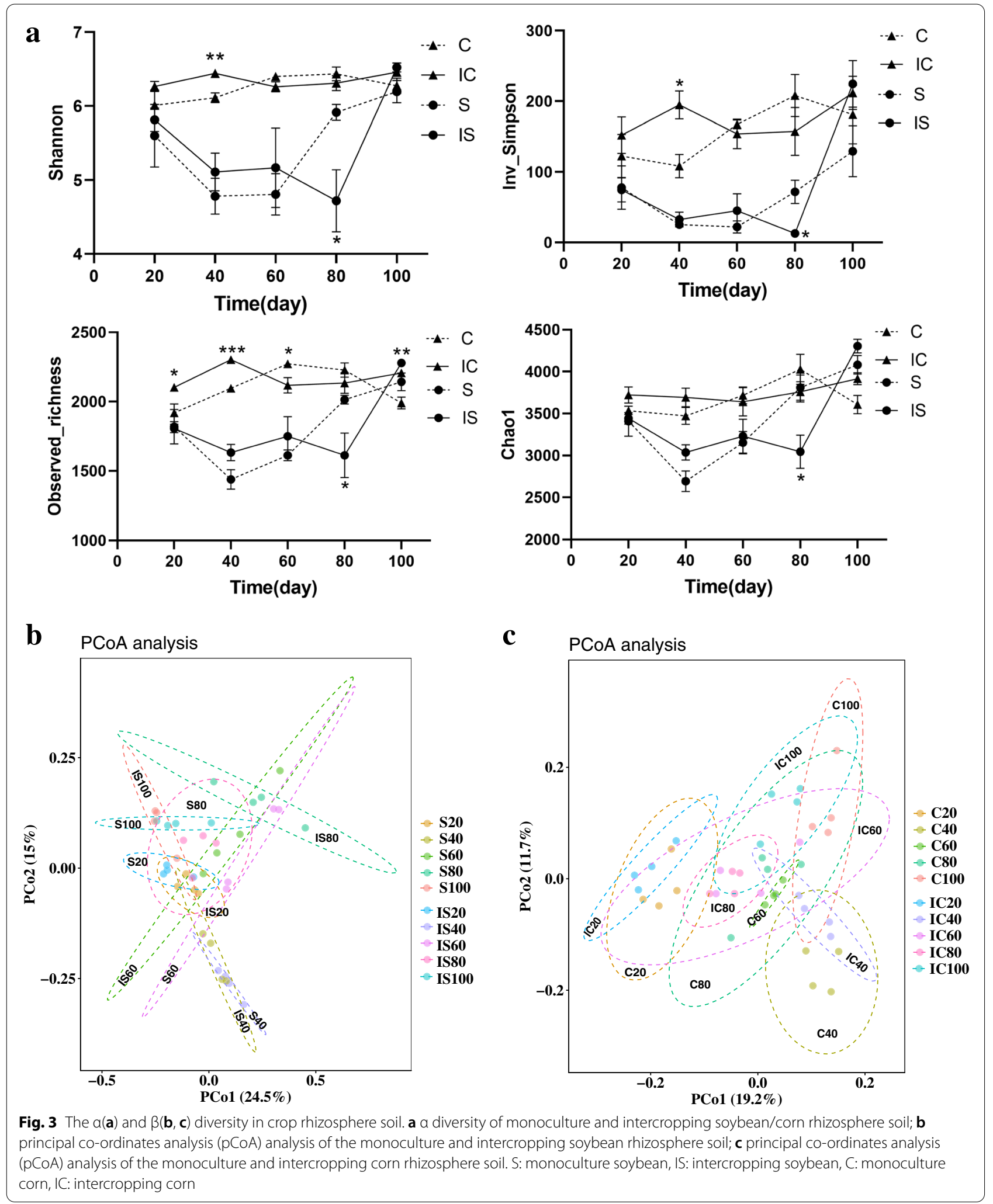


Table 1 The properties of the empirical and random networks under different cultivation mode. S: monoculture soybean, IS: intercropping soybean, C: monoculture corn, IC: intercropping corn

\begin{tabular}{|c|c|c|c|c|c|c|c|c|c|}
\hline \multirow[t]{2}{*}{ Groups } & \multicolumn{6}{|c|}{ Empirical Network } & \multicolumn{3}{|c|}{ Random networks(100) } \\
\hline & RMT threshold & nodes & links & $\begin{array}{l}\text { Average } \\
\text { degree } \\
\text { (avgK) }\end{array}$ & $\begin{array}{l}\text { Average } \\
\text { clustering } \\
\text { coefficient } \\
\text { (avgCC) }\end{array}$ & $\begin{array}{l}\text { Modularity } \\
\text { (fast_greedy) }\end{array}$ & $\begin{array}{l}\text { Average } \\
\text { clustering } \\
\text { coefficient } \\
\text { (avgCC) }\end{array}$ & $\begin{array}{l}\text { Average path } \\
\text { distance } \\
\text { (GD) }\end{array}$ & $\begin{array}{l}\text { Modularity } \\
\text { (fast_greedy) }\end{array}$ \\
\hline $\mathbf{S}$ & 0.8 & 537 & 1380 & 5.14 & 0.157 & 0.524 & $0.046+/-0.005$ & $3.581+/-0.034$ & $0.398+/-0.005$ \\
\hline IS & 0.8 & 574 & 1710 & 5.958 & 0.185 & 0.562 & $0.051+/-0.005$ & $3.445+/-0.032$ & $0.358+/-0.004$ \\
\hline C & 0.8 & 581 & 918 & 3.16 & 0.123 & 0.793 & $0.011+/-0.003$ & $4.549+/-0.054$ & $0.600+/-0.006$ \\
\hline IC & 0.8 & 500 & 550 & 2.2 & 0.058 & 0.814 & $0.005+/-0.003$ & $5.620+/-0.157$ & $0.772+/-0.007$ \\
\hline
\end{tabular}

The mantel test and canonical correspondence analysis (CCA) were performed to assess correlations between physicochemical properties and bacterial community composition (Table 2 and Fig. 5a, b). The results showed that soil organic matter was significantly positively correlated with rhizosphere soil bacterial communities in the monocropped and intercropped soybean and that AP, AK and AN were significantly positively correlated with the rhizosphere soil bacterial communities in monocropped and intercropped corn $(P<0.05$, Table 2). According to the CCA-based variation partitioning analysis (VPA) results, $4.45,4.61,4.35$ and $10.14 \%$ of the variation in the rhizosphere soil bacterial community in the monocropped and intercropped soybean systems could be respectively explained by the $\mathrm{pH}$; $\mathrm{SOM}$; $\mathrm{ACd}$; and $\mathrm{AP}$, AK, and AN (Fig. 5c). Moreover, their interaction could explain $11.16 \%$ of the variation, leaving $69.74 \%$ of the variation unexplained (Fig. 5c). In addition, 4.30, 3.12, 2.48 and $14.91 \%$ of the variation in the rhizosphere soil bacterial communities in the monocropped and intercropped corn systems could be respectively explained by the $\mathrm{pH}$; SOM; ACd; and AP, AK, and AN (Fig. 5d). Their interaction could explain $0.34 \%$ of the variation, leaving $74.85 \%$ of the variation unexplained (Fig. $5 \mathrm{~d}$ ).

\section{Discussion}

The effects of intercropping on $\mathrm{Cd}$ accumulation in plants were different. In our study, the dynamic trends of plant $\mathrm{Cd}$ were consistent between the intercropping and monocropping systems throughout growing season. The cadmium concentration of corn straw gradually decreased with increasing time after sowing, whereas the cadmium concentration of soybean straw first gradually increased and then decreased with increasing time after sowing. These results strongly agree with the previous findings that $\mathrm{Cd}$ concentration of plants was not significantly affected in grape and Solanum nigrum L. [25]. Furthermore, another study found that the $\mathrm{Cd}$ concentration of shoot cells in intercropped $V$. faba shoot cells was greater than that of monocropped shoot cells [26]. These results may be due to the plant species used, change in plant rhizosphere environments due to intercropping and effects on plant absorption of heavy metals [26, 27].

Compared with monocropping, intercropping can change soil nutrient composition [28]. In this study, the AP and SOM concentrations were higher in the IC and IS groups than in their corresponding monocultures, which is consistent with the previous observations $[24,29,30]$. The concentration of AP was significantly higher in the intercropping system than in the monocultures. Alternatively, this phenomenon may have resulted from greater nitrogen fixation, which can acidify the rhizosphere soil of legumes and activate the organophosphorus in the soil, compared to that from the monoculture [31]. The soil AK concentration in the IS samples was also higher than that in the corresponding monoculture samples. This results might be explained by differences in nutrient use, given that intercropping affected the soil nutrient pool [32]. The AN concentration in soil under corn gradually decreased, whereas that in soybean gradually increased and then decreased. In addition, soil AN concentration were higher under intercropped corn than under monoculture corn except on day 100. These results were likely due to nitrogen fixation by soybean and improved supply of nitrogen to intercropped corn and soybean, with corn undergoing increased $N$ uptake [33, 34].

Slight acidification in the rhizosphere was observed with the growth of soybean, which is consistent with results typically observed in common bean [35]. Changes in rhizosphere soil $\mathrm{pH}$ depend on cation-anion balance, which is greatly affected by nitrogen nutrition [36]. In this experiment, the rhizosphere $\mathrm{pH}$ in IS and $\mathrm{S}$ treatment was different. The rhizosphere $\mathrm{pH}$ in IS was significantly lower than that in the monoculture on day 60. It may have resulted from an increase in proton 


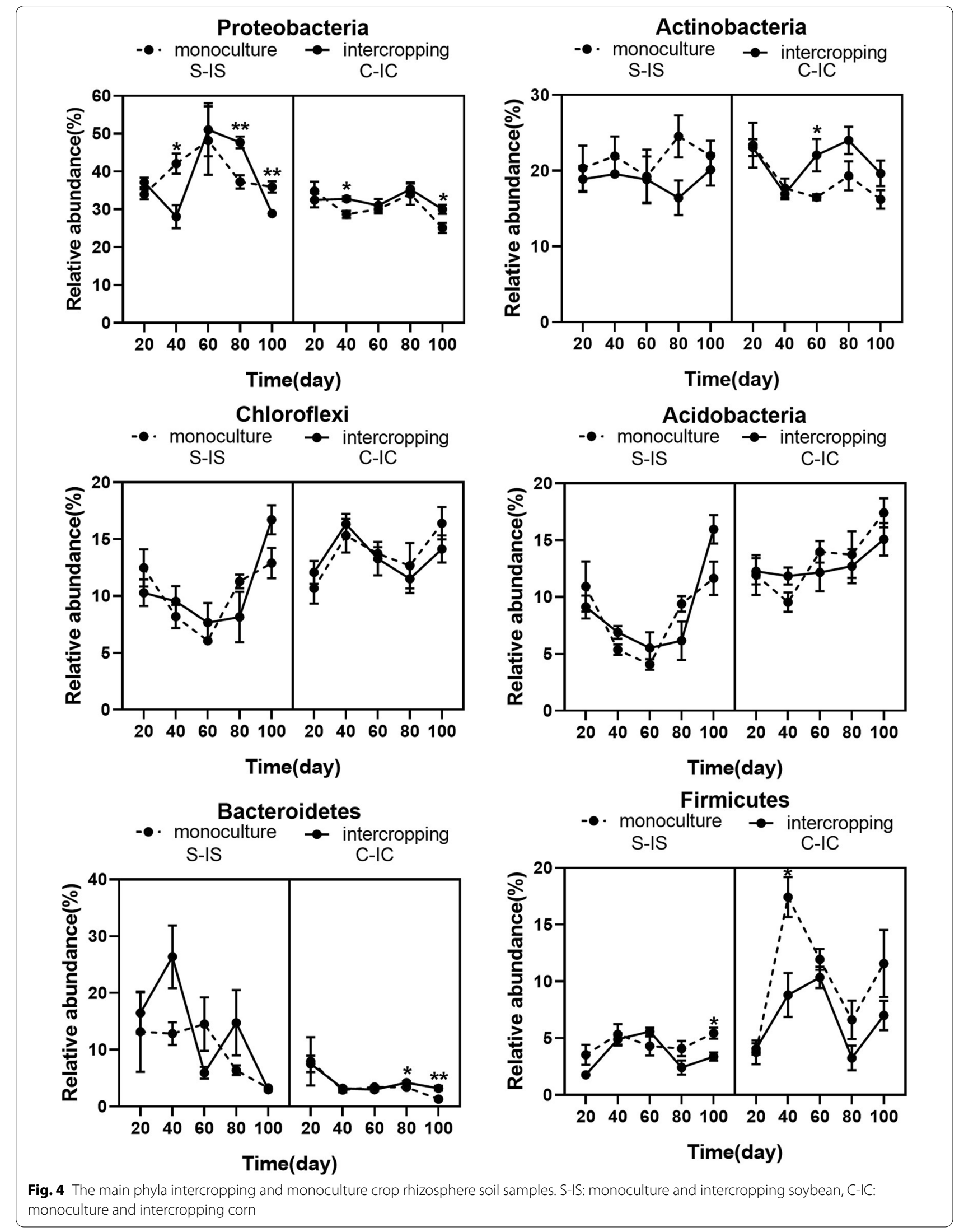


Table 2 The mantel analysis based on Bray_curtis distance under different cultivation modes. S: monoculture soybean, IS: intercropping soybean, C: monoculture corn, IC: intercropping corn. SOM: soil organic matter, AP: available phosphorus, AN: available nitrogen, AK: available kalium. S_IS: monoculture and intercropping soybean, C_IC: monoculture and intercropping corn

\begin{tabular}{|c|c|c|c|c|}
\hline \multirow[t]{2}{*}{ Factors } & \multicolumn{2}{|l|}{ S_IS } & \multicolumn{2}{|l|}{ C_IC } \\
\hline & $r$ & $p$ & $r$ & $p$ \\
\hline pH & 0.0467 & 0.287 & 0.138 & 0.072 \\
\hline SOM & 0.1405 & * & 0.0374 & 0.339 \\
\hline AP & 0.0813 & 0.134 & 0.2838 & * \\
\hline AN & 0.0578 & 0.233 & 0.2276 & $* *$ \\
\hline AK & 0.1098 & 0.107 & 0.3041 & $* *$ \\
\hline $\mathrm{ACd}$ & 0.0827 & $*$ & -0.0378 & 0.607 \\
\hline
\end{tabular}

release by the intercropped soybean due to greater $\mathrm{N}_{2}$ fixation compared to the sole crop, as a consequence of acidification is expected to occur when the amount of proton released when the intensity of $\mathrm{N}_{2}$ fixation by soybean [37]. By contrast, rhizosphere $\mathrm{pH}$ in IS was significantly higher than that in the monocropped on day 100. This result might be explained by lower $\mathrm{N}_{2}$ fixation that occurred in intercropped soybean than in the monoculture with crop growth. In the rhizosphere of corn, alkalization was observed in the monocropped or intercropped with corn intercropping systems, which is in line with the previous results $[24,29]$. The rhizosphere $\mathrm{pH}$ of the IC was significantly lower than that in the monocropped on day 60 . This result might be explained by interspecific competition for the uptake of inorganic $\mathrm{N}$ forms [38], with intercropped corn being more competitive than the monocropped corn in accessing nitrate. Rhizosphere soil $\mathrm{pH}$ in IC and IS was higher than that in corresponding monocultures at $100 \mathrm{~d}$. The $\mathrm{pH}$ of all the samples from the soybean soil all decreased, while that of the corn soil increased, but no significant acidification was observed in rhizosphere soil. Fu et al. [24] and Betencourt et al. [29] reported similar results.

The rhizosphere soil ACd increased first and then decreased in IS, whereas the pattern was the opposite in the corresponding monoculture. The changes in corn rhizosphere soil ACd were opposite to those in soybean. The concentrations of ACd in IS and IC groups were significantly different from those in corresponding monoculture from day 40 , and the differences of ACd concentrations between the monocultures and intercropping systems gradually decreased with cultivation time, which may be due to the roots of the intercropped plants secreting numerous organic acids and consequently altering the mobility of soil $\mathrm{Cd}$ in the intercropping systems $[39,40]$. However, there were significant differences in ACd concentration between IS and S, which indicated that the soybean activated the soil $\mathrm{Cd}$ [41] . Consequently, the results showed that the soybean-corn intercropping system altered the cadmium concentrations in cadmium-polluted soil.

Soil microorganisms participate in many ecological processes and greatly influence soil quality and function [42]. The dominant phyla in soybean and corn rhizosphere soil were Proteobacteria, Chloroflexi, Acidobacteria, Actinobacteria and Firmicutes, which is similar to results reported in previous studies [24]. The main phyla were similar in rhizosphere of the same crop in monoculture and intercropping systems, but there were slight differences at all growth stages. The significant differences in the main phyla were observed between soybean and corn rhizosphere soil, likely because of the crop species genotype $[43,44]$. Comparing the bacterial community diversity of soybean and corn under the two planting modes, we also found that the same crop showed little difference under the two planting modes [45]. However, the bacterial community diversity was significantly higher in corn rhizosphere soil than in the soybean rhizosphere soil. Therefore, compared with that of the soybean soil, the bacterial diversity of the maize soil was enriched, which might have affected the absorption of ACd by corn.

The network interactions within the rhizosphere bacterial communities of the four different groups were also analysed. Owing to their relatively strong robustness and consistency, networks based on random matrix theory could accurately reflect various complex biological systems because of relatively strong robustness and consistency [46]. In general, a more complex network indicates a more stable community structure $[47,48]$. In this study, the modularity values for all the groups were higher than those of corresponding randomized networks (Table 1), which indicated all pMENs appear to be modular [49]. Interspecies interaction was significantly different between intercropped and monoculture crop species. There were significantly more bacterial network nodes and links in the IS group compared with the corresponding monoculture crop group but significantly fewer in the IC group (Table 1). Therefore, the network within intercropped soybean was more complex than that in the monoculture, whereas the network within intercropped corn was simpler than that in the monoculture. Thus, soybean-corn intercropping affected the cooccurrence network patterns of the rhizosphere bacterial communities.

There were large changes among these module hubs and connectors between the intercropped and 


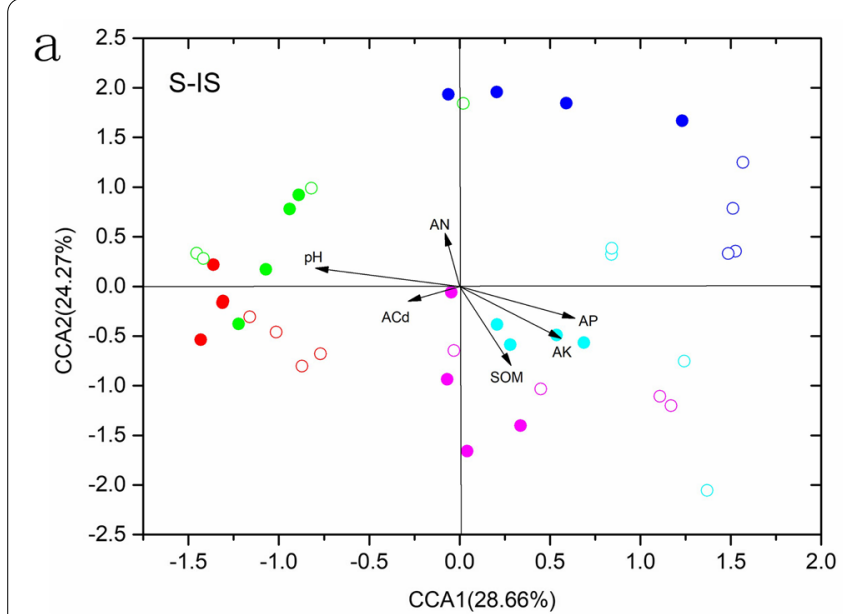

C
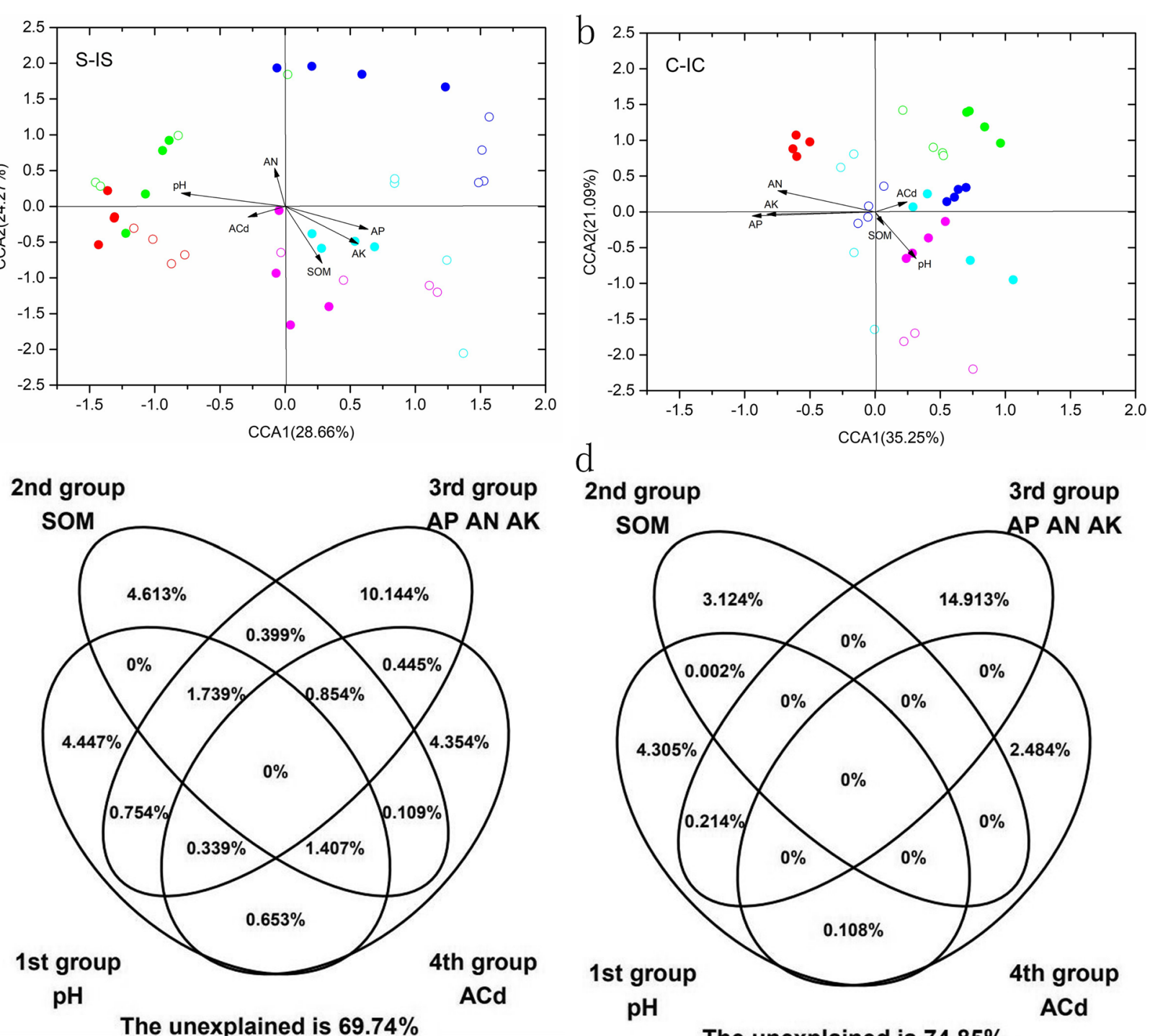

d

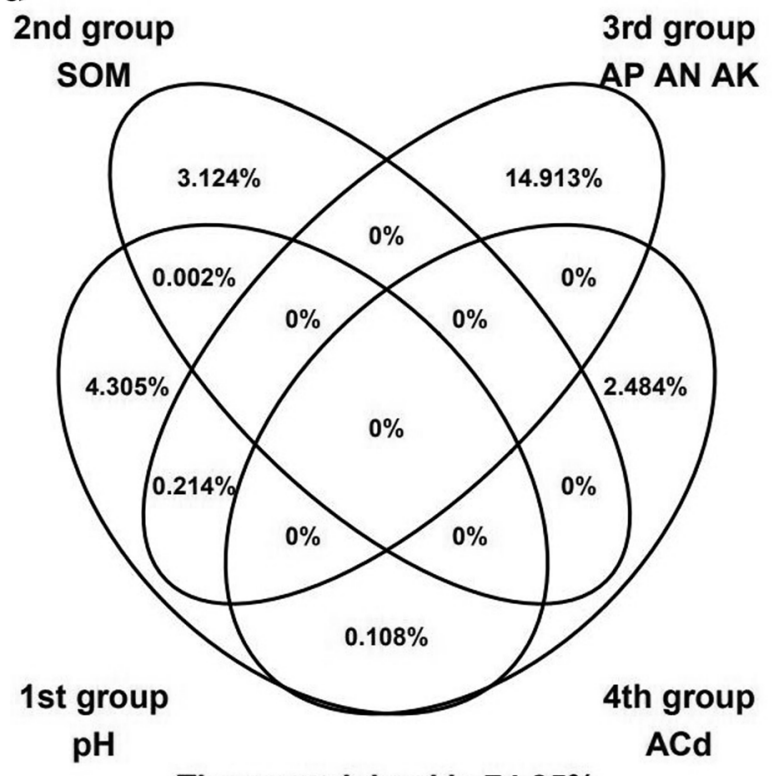

The unexplained is $\mathbf{7 4 . 8 5 \%}$

Fig. 5 The CCA $(\mathbf{a}, \mathbf{b})$ and CCA-based VPA (c, d) between intercropping and monoculture crop rhizosphere soil samples. a CCA of intercropping and monoculture soybean; $\mathbf{b}$ CCA of intercropping and monoculture corn; c CCA-based VPA of intercropping and monoculture soybean; $\mathbf{d}$ CCA-based VPA of intercropping and monoculture corn. Solid circle: intercropping soybean/corn; hollow circle: monoculture soybean/corn. Red: 20 day, green: 40 day, blue: 60 day, cyan: 80 day, magenta: 100 day

monocropped soybean and corn networks (Table S3). These changes may have occurred because of ubiquitous taxa with specific functions. These shared species of different soils take apart in plant-microbe interactions through their functions [50,51], while keystone species are generally crucial for determining ecological functions and ecosystem stability of an entire ecological network $[52,53]$. However, we still lacked a comprehensive understanding of these shared and key species. Therefore, further research is needed to provide direct evidence for network analysis of complex microbial communities.
In our study, we found a slight difference in bacterial diversity, but the bacterial communities of intercropped and corresponding monocropped soybean were significantly different at 20,40 and 80d, while those of maize were significantly different at the 40 and $60 \mathrm{~d}$. This result indicated that cultivation time is also an important factor affecting rhizosphere bacterial community except for crop the planting pattern [49]. While these rhizosphere microorganisms also regulate the rhizosphere soil environment through plant-microbe interactions [50]. It also will be our next research focus that regulating the cadmium 
concentration in cadmium-contaminated soil through plant-microbial interactions.

\section{Conclusion}

Compared with monocropping, intercropping led to increased concentrations of AP and SOM in rhizosphere soils of soybean and corn compared with those in corresponding monoculture. Changes in soil nutrients due to intercropping were determined to be important factors in determining the structure and diversity of bacterial communities. Soil organic matter and ACd were significantly correlated with bacterial communities of soybean, whereas AP, AN, and AK were key factors affecting communities in corn rhizosphere soils. The findings suggested that intercropping increased stability of soybean rhizosphere community structure but decreased the stability of the corn rhizosphere community structure. However, further research is still needed to provide direct evidence for network analyses on complex microbial communities in a cooperative environment. These results provide important insights into how soil ACd, soil nutrients, and bacterial diversity are affected via plantmicrobe interactions in legume-cereal intercropping agroecosystems in $\mathrm{Cd}$-contaminated soils.

\section{Materials and methods}

\section{Site description, experimental design and sample} collection

The experiment was conducted in Zhuzhou City $\left(27^{\circ} 43^{\prime} 25.6^{\prime \prime} \mathrm{N}, 113^{\circ} 8^{\prime} 3.8^{\prime \prime} \mathrm{E}\right)$, Hunan Province, China. The region has a subtropical monsoon humid climate, the average annual temperature is $17.5^{\circ} \mathrm{C}-18^{\circ} \mathrm{C}$, the average rainfall amount is $1400-1500 \mathrm{~mm}$, and the average annual sunshine is $1500 \mathrm{~h}-1600 \mathrm{~h}$. The field experiment included two monocropping systems, monocropped corn $(\mathrm{C})$ and monoculture soybean (S), and soybeancorn intercropping system (ICS) in a typical cadmiumpolluted fallow zone. The plants used were compact and high-cadmium accumulating corn (Denghai 605) and a major soybean cultivars (Xiangchundou 26) grown in Hunan Province. Corn and soybean were sown on April 6, 2019, and harvested on July 30, 2019. The soil chemical properties in the top $20 \mathrm{~cm}$ were as follows: $\mathrm{pH} 5.51$, total $\mathrm{Cd} 1.98 \mathrm{mg} \cdot \mathrm{kg}^{-1}$, available $\mathrm{Cd} 1.16 \mathrm{mg} \cdot \mathrm{kg}^{-1}$, total $\mathrm{N} 1.99 \mathrm{~g} \cdot \mathrm{kg}^{-1}$, organic matter $31.3 \mathrm{~g} \cdot \mathrm{kg}^{-1}$; total $\mathrm{P}$, $0.626 \mathrm{~g} \cdot \mathrm{kg}^{-1}$; total $\mathrm{K}, 11.1 \mathrm{~g} \cdot \mathrm{kg}^{-1}$; alkali hydrolysable $\mathrm{N}$, $112 \mathrm{mg} \cdot \mathrm{kg}^{-1}$; Olsen-P, $12.6 \mathrm{mg} \cdot \mathrm{kg}^{-1}$; and exchangeable $\mathrm{K}$, $64 \mathrm{mg} \cdot \mathrm{kg}^{-1}$.

In the soybean-corn intercropping system, the ratio of corn rows to soybean rows was 2:3. In the monoculture system, the row spacings of the corn and soybean plants were $60 \mathrm{~cm}$ and $33 \mathrm{~cm}$, respectively. The plant spacings of the corn plants and soybean plants were $32 \mathrm{~cm}$ and $60 \mathrm{~cm}$, respectively. The distance between corn and soybean rows was $60 \mathrm{~cm}$ (Fig. 6). The planting density for corn was $52,500 \mathrm{hm}^{-2}$, and for soybean was $150,000 \mathrm{hm}^{-2}$. The intercropping systems were planted at same density, but the plant spacings of corn and soybean plants were $16 \mathrm{~cm}$ and $30 \mathrm{~cm}$, respectively. The plot size was $30 \mathrm{~m}^{2}$, and each treatment was applied in four replicate plots. The nitrogen fertilization for corn was divided into two parts, $112.5 \mathrm{~kg} \cdot \mathrm{hm}^{-2}$ for base fertilizer and $105.75 \mathrm{~kg} \cdot \mathrm{hm}^{-2}$ for topdressing. The phosphorus and potassium fertilization were used as base fertilizer at $112.5 \mathrm{~kg} \cdot \mathrm{hm}^{-2}$ and $112.5 \mathrm{~kg} \cdot \mathrm{hm}^{-2}$ for corn. The nitrogen, phosphorus and potassium fertilization were used as base fertilizer $67.5 \mathrm{~kg} \cdot \mathrm{hm}^{-2}, 67.5 \mathrm{~kg} \cdot \mathrm{hm}^{-2}$ and $67.5 \mathrm{~kg} \cdot \mathrm{hm}^{-2}$ for soybean. In IMS, the nitrogen topdressing for IM applied with a distance of $40 \mathrm{~cm}$ from the maize rows to the soybean rows. There was no irrigation applied during crop growth.

Plant and rhizosphere soil samples were collected at 20, $40,60,80$ and 100 days after sowing. In each plot, samples were randomly collected from five points and mixed into one composite sample. The plant samples were separated into straw (stems and leaves) and grain, which were then weighed after oven-drying $80^{\circ} \mathrm{C}$ until a constant weight was achieved. The rhizosphere soil was collected by shaking plant roots. The rhizosphere soil samples were divided into two parts. One part was used for DNA extraction, and the other part was air-dried and used for analyze soil property analysis.

\section{Determination of plant and soil physiochemical properties}

The soil $\mathrm{pH}$ was measured via potentiometry with a $\mathrm{pH}$ meter (PB-10, Sartorious, Germany). Soil available cadmium (ACd) was extracted with calcium chloride [54]. Plant samples were digested in a mixture of $\mathrm{HNO}_{3}$ and $\mathrm{HClO}_{4}$. The concentration of $\mathrm{ACd}$ and $\mathrm{Cd}$ were measured with graphite furnace atomic absorption spectrometry (ZEEnit 700 P, Analytik Jena AG, Germany). The concentrations of soil organic matter (SOM) and available nitrogen (AN) were measured using volumetric methods [55, 56]. The concentration of available phosphorus (AP) was measured by UV-Vis spectrophotometry [56]. Available potassium (AK) was determined by the inductively coupled plasma-atomic emission spectrometry (ICP-AES).

\section{DNA extraction, PCR amplification and pyrosequencing}

In total, 80 rhizosphere soil samples were collected and sequenced. The soil DNA was extracted using a Fast DNA Spin Kit for soil (MP Biomedicals LLC, USA) according to the manufacturer's instructions. DNA was stored at $-20^{\circ} \mathrm{C}$ before use. The V3-V4 region of the $16 \mathrm{~S}$ rRNA gene was amplified with primer pair $338 \mathrm{~F}$ 


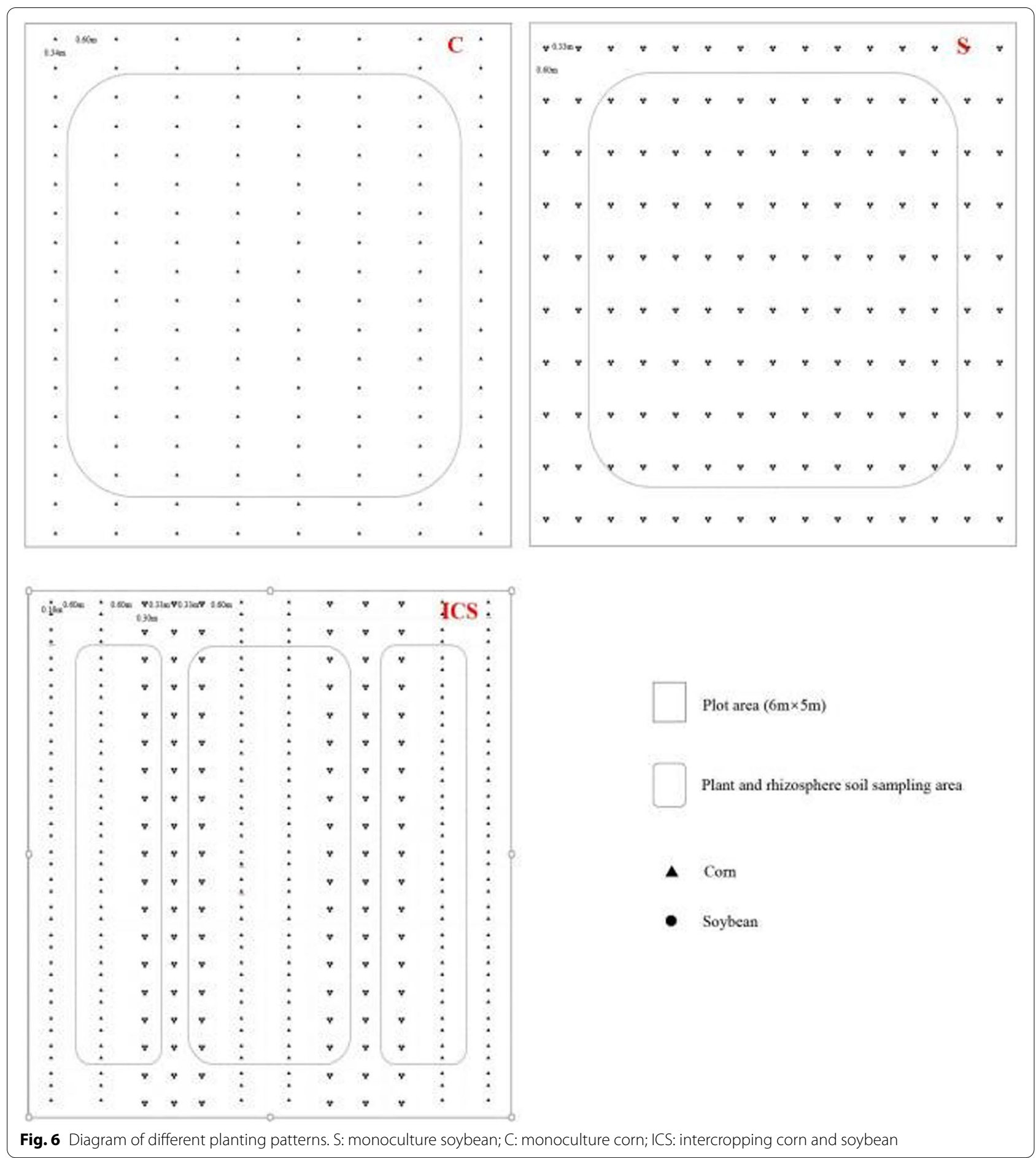

(5'-ACTCCTACGGGAGGCAGCAG-3') and 806R (5'GGACTACHVGGGTWTCTAAT-3') [57]. Both the forward and reverse primers were tagged with unique barcodes to distinguish different samples. PCR and sequencing were performed at Majorbio Bio-Pharm
Technology Co. Ltd., Shanghai, China. Sequencing was performed on an Illumina MiSeq platform using a PE250 kit. The sequencing data were deposited in the NCBI Sequence Read Archive database under BioProject ID PRJNA662201. 


\section{Data and statistical analyses}

Data analysis was performed using the open, webbased platform, Galaxy (http://mem.rcees.ac.cn:8080) [58]. Briefly, $12 \mathrm{bp}$ barcode sequences were used to separate the different soil samples. The forward and reverse sequences were then combined with a minimum 30 bp overlap length and a maximum $250 \mathrm{bp}$ maximum overlap length using the FLASH program [59]. Combined sequences with low quality were removed. Subsequently, the reads were clustered into operational taxonomic units (OTUs) with 97\% similarity using UPARSE [60]. The OTU table was resampled with 17,093 sequences.

The $\alpha$-diversity indices and the relative abundances of phyla and genera were calculated in this study. Differences in microbial community structure were investigated by weighted principal coordinate analysis (PCoA) based on weighted UniFrac matrix and dissimilarity tests (nonparametric permutational multivariate analysis of variance (PERMANOVA) test based on Bray Curtis) [61, 62]. The Mantel test was used to evaluate the correlations between physicochemical properties and the microbial communities. The canonical correspondence analysis (CCA) and CCAbased variation partitioning analysis (VPA) were further performed to determine the relative contribution of environmental variables to the bacterial community. To evaluate the differences in soil physicochemical properties between the intercropped and corresponding monocropped soybean and corn samples during various stages, Student's $t$ tests were performed in the Excel 2017.

\section{The network analysis}

Phylogenetic molecular ecological networks (pMENs) of the four treatment groups (S, IS, C and IC) were constructed based on Spearman rank correlation matrices using the molecular ecological network analysis pipeline (MENA, http://ieg4.rcc.ou.edu/mena/login.cgi) [46, $63,64]$. The process was followed as described by Deng [64], and the correlations only above a specific threshold $(0.80)$ were used to calculating the network eigenvalues. The network plots were visualized with the software Cytoscape 3.6.0.

\footnotetext{
Abbreviations

SOM: Soil organic matter; AP: Available phosphorus; ACd: Available cadmium; AN: Available nitrogen; AK: Available potassium; pCoA: The principal coordinate analysis; ADONIS: Nonparametric parametric permutational multivariate analysis of variance of the Adonis function; OTU: Operational taxonomic unit; PERMANOVA: Nonparametric permutational multivariate analysis of variance.
}

\section{Supplementary Information}

The online version contains supplementary material available at https://doi. org/10.1186/s12866-022-02468-3.

Additional file 1.

Additional file 2.

Additional file 3.

Additional file 4.

Additional file 5 .

Additional file 6.

\section{Acknowledgments}

The authors thank the Crop Research Institute of Hunan Province for their support in this experiment.

\section{Authors' contributions}

$\mathrm{HL}$ and $\mathrm{LYL}$ designed the experiments, BT, HLG, ZYC, QZ and SLC performed the experiments, $\mathrm{HL}$ and $\mathrm{LYL}$ analysed the data, $\mathrm{HL}$ prepared figures and tables, LYL and ZHC revised the language of the manuscript. All the authors read and approved the final manuscript.

\section{Funding}

This work was supported by the Maize of China Agricultural Research System (CARS-02), Safety Evaluation of Low Cd Accumulation Edible Crops (Xiang Cai Nong Zhi, 2019, No.33), and the Natural Science Foundation of Hunan (2018JJ3320)

Availability of data and materials

All study data are included in the manuscript and its additional files. The sequencing data were deposited in the NCBI Sequence Read Archive database under BioProject ID PRJNA662201.

\section{Declarations}

\section{Ethics approval and consent to participate}

The Ethics Committee of Crop Research Institute, Hunan Academy of Agricultural Sciences and Yangtze Normal University approved this study.

The authors confirm that all the experimental methods and plants complied with relevant institutional, national, and international guidelines and legislation.

\section{Consent for publication}

Not applicable.

\section{Competing interests}

The authors declare that they have no competing interests.

Received: 23 August 2021 Accepted: 31 January 2022

Published online: 15 February 2022

\section{References}

1. Xu ZM, Tan XQ, Mei XQ, Li QS, Zhou C, Wang LL, et al. Low-Cd tomato cultivars (Solanum lycopersicum L.) screened in non-saline soils also accumulated low Cd, Zn, and Cu in heavy metal-polluted saline soils. Environ Sci Pollut Res. 2018;25(27):27439-50.

2. Su H, Zou T, Lin R, Zheng J, Jian S, Zhang M. Characterization of a phytochelatin synthase gene from Ipomoea pes-caprae involved in cadmium tolerance and accumulation in yeast and plants. Plant Physiol Biochem. 2020;155:743-55.

3. Zou M, Zhou S, Zhou Y, Jia Z, Guo T, Wang J. Cadmium pollution of soil-rice ecosystems in rice cultivation dominated regions in China: a review. Environ Pollut. 2021;280:116965. 
4. El-Hassanin AS, Samak MR, Abdel-Rahman GN, Abu-Sree YH, Saleh EM. Risk assessment of human exposure to lead and cadmium in maize grains cultivated in soils irrigated either with low-quality water or freshwater. Toxicol Rep. 2020;7:10-5.

5. Romero-Estévez D, Yánez-Jácome GS, Simbaña-Farinango K, Vélez-Terreros PY, Navarrete $\mathrm{H}$. Determination of cadmium and lead in tomato (Solanum lycopersicum) and lettuce (Lactuca sativa) consumed in Quito, Ecuador. Toxicol Rep. 2020;7:893-9.

6. Welikala D, Robinson BH, Moltchanova E, Hartland A, Lehto NJ. Soil cadmium mobilisation by dissolved organic matter from soil amendments. Chemosphere. 2021;271:129536.

7. Mendes R, Garbeva P, Raaijmakers JM. The rhizosphere microbiome: significance of plant beneficial, plant pathogenic, and human pathogenic microorganisms. FEMS Microbiol Rev. 2013;37(5):634-63.

8. Manching HC, Balint-Kurti PJ, Stapleton AE. Southern leaf blight disease severity is correlated with decreased maize leaf epiphytic bacterial species richness and the phyllosphere bacterial diversity decline is enhanced by nitrogen fertilization. Frontiers. Plant Sci. 2014;5:403.

9. Coskun D, Britto DT, Shi W, Kronzucker HJ. How plant root exudates shape the nitrogen cycle. Trends Plant Sci. 2017;22(8):661-73.

10. Yin C, Fan F, Song A, Cui P, Li T, Liang Y. Denitrification potential under different fertilization regimes is closely coupled with changes in the denitrifying community in a black soil. Appl Microbiol Biotechnol. 2015;99(13):5719-29.

11. Vandermeer J, van Noordwijk M, Anderson J, Ong C, Perfecto I. Global change and multi-species agroecosystems: concepts and issues. Agric Ecosyst Environ. 1998;67(1):1-22.

12. Hong $Y$, Heerink $N$, Jin S, Berentsen $P$, Zhang L, van der Werf W. Intercropping and agroforestry in China - current state and trends. Agric Ecosyst Environ. 2017;244:52-61.

13. Luo SS, Yu LL, Liu Y, Zhang Y, Yang W, Li ZX, et al. Effects of reduced nitrogen input on productivity and N2O emissions in a sugarcane/soybean intercropping system. Eur J Agron. 2016;81:78-85.

14. Martin-Guay M-O, Paquette A, Dupras J, Rivest D. The new green revolution: sustainable intensification of agriculture by intercropping. Sci Total Environ. 2018;615:767-72.

15. Li X, Sun M, Zhang H, Xu N, Sun G. Use of mulberry-soybean intercropping in salt-alkali soil impacts the diversity of the soil bacterial community. Microb Biotechnol. 2016;9(3):293-304.

16. Chen C, Liu W, Wu J, Jiang X, Zhu X. Can intercropping with the cash crop help improve the soil physico-chemical properties of rubber plantations? Geoderma. 2019;335:149-60.

17. Zeng P, Guo Z, Xiao X, Peng C. Dynamic response of enzymatic activity and microbial community structure in metal(loid)-contaminated soil with tree-herb intercropping. Geoderma. 2019;345:5-16.

18. Zeng P, Guo Z, Xiao X, Peng C. Effects of tree-herb co-planting on the bacterial community composition and the relationship between specific microorganisms and enzymatic activities in metal(loid)-contaminated soil. Chemosphere. 2019;220:237-48.

19. Wan J, Bao H, Peng W, An I, Jiang Q, Yang J, Zhu C. Effects of intercropping on cadmium uptake by maize and tomato. Chin J Biotechnol. 2020;36(03):518-28.

20. Yang F, Liao D, Wu X, Gao R, Fan Y, Raza MA, et al. Effect of aboveground and belowground interactions on the intercrop yields in maize-soybean relay intercropping systems. Field Crop Res. 2017;203:16-23.

21. Du JB, Han TF, Gai JY, Yong TW, Sun X, Wang XC, et al. Maize-soybean strip intercropping: achieved a balance between high productivity and sustainability. J Integr Agric. 2018;17(4):747-54.

22. Yong T, Liu X, Yang F, Song C, Wang X, Liu W, et al. Characteristics of nitrogen uptake, use and transfer in a wheat-maize-soybean relay intercropping system. Plant Prod Sci. 2015;18(3):388-97.

23. Chen $P, D u$ Q, Liu X, Zhou L, Hussain S, Lei L, et al. Effects of reduced nitrogen inputs on crop yield and nitrogen use efficiency in a longterm maize-soybean relay strip intercropping system. PLoS One. 2017;12(9):e0184503.

24. Fu ZD, Zhou L, Chen P, Du Q, Pang T, Song C, et al. Effects of maizesoybean relay intercropping on crop nutrient uptake and soil bacterial community. J Integr Agric. 2019;18(9):2006-18.

25. Hu R, Zhang Z, Lin L, Ma L, Tang Y, Liang D, et al. Intercropping with hyperaccumulator plants decreases the cadmium accumulation in grape seedlings. Acta Agriculturae Scandinavica, section B — Soil \& Plant. Science. 2019;69(4):304-10.

26. Li ZR, Wang JX, An LZ, Tan JB, Zhan FD, Wu J, et al. Effect of root exudates of intercropping Vicia faba and Arabis alpina on accumulation and sub-cellular distribution of lead and cadmium. Int J Phytoremediation. 2019;21(1):4-13.

27. Li L, Sun JH, Zhang FS. Intercropping with wheat leads to greater root weight density and larger below-ground space of irrigated maize at late growth stages. Soil Sci Plant Nutr. 2011;57(1):61-7.

28. Li Q, Chen J, Wu L, Luo X, Li N, Arafat Y, et al. Belowground interactions impact the soil bacterial community, soil fertility, and crop yield in maize/ peanut intercropping systems. Int J Mol Sci. 2018;19(2):622.

29. Betencourt E, Duputel M, Colomb B, Desclaux D, Hinsinger P. Intercropping promotes the ability of durum wheat and chickpea to increase rhizosphere phosphorus availability in a low P soil. Soil Biol Biochem. 2012;46:181-90.

30. Li L, Zhang F, Li X, Christie P, Sun J, Yang S, et al. Interspecific facilitation of nutrient uptake by intercropped maize and faba bean. Nutr Cycl Agroecosyst. 2003;65(1):61-71.

31. Li L, Tang C, Rengel Z, Zhang F. Chickpea facilitates phosphorus uptake by intercropped wheat from an organic phosphorus source. Plant Soil. 2003;248(1):297-303.

32. Schloter M, Dilly O, Munch JC. Indicators for evaluating soil quality. Agric Ecosyst Environ. 2003;98(1):255-62.

33. Fan F, Zhang F, Song Y, Sun J, Bao X, Guo T, et al. Nitrogen fixation of faba bean (Vicia faba L.) interacting with a non-legume in two contrasting intercropping systems. Plant Soil. 2006;283(1):275-86.

34. Xiao Y, Li L, Zhang F. Effect of root contact on interspecific competition and $\mathrm{N}$ transfer between wheat and fababean using direct and indirect $15 \mathrm{~N}$ techniques. Plant Soil. 2004;262(1):45-54.

35. Li H, Shen J, Zhang F, Clairotte M, Drevon JJ, Le Cadre E, et al. Dynamics of phosphorus fractions in the rhizosphere of common bean (Phaseolus vulgaris L.) and durum wheat (Triticum turgidum durum L.) grown in monocropping and intercropping systems. Plant Soil. 2008;312(1):139-50.

36. Hinsinger $P$, Plassard $C$, Tang C, Jaillard B. Origins of root-mediated $\mathrm{pH}$ changes in the rhizosphere and their responses to environmental constraints: a review. Plant Soil. 2003;248(1):43-59.

37. Tang C, Unkovich MJ, Bowden JW. Factors affecting soil acidification under legumes. III. Acid production by N2-fixing legumes as influenced by nitrate supply. New Phytol. 1999;143(3):513-21.

38. Miller AE, Bowman WD, Suding KN. Plant uptake of inorganic and organic nitrogen: neighbor identity matters. Ecology. 2007;88(7):1832-40.

39. Das S, Chou ML, Jean JS, Yang HJ, Kim PJ. Arsenic-enrichment enhanced root exudates and altered rhizosphere microbial communities and activities in hyperaccumulator Pteris vittata. J Hazard Mater. 2017;325:279-87.

40. Li NY, Li ZA, Ding YZ, Zou B, Zhuang P. Effects of intercropping different crops with maize on the cd uptake by maize. J Appl Ecol. 2008;19(6):1369-73.

41. Zhu S, Ma X, Guo R, Ai S, Liu B, Zhang W, et al. A field study on heavy metals phytoattenuation potential of monocropping and intercropping of maize and/or legumes in weakly alkaline soils. Int J Phytoremediation. 2016;18(10):1014-21.

42. Rovira AD. Interactions between plant roots and soil microorganisms. Annu Rev Microbiol. 1965;19(1):241-66.

43. Correa OS, Romero AM, Montecchia MS, Soria MA. Tomato genotype and Azospirillum inoculation modulate the changes in bacterial communities associated with roots and leaves. J Appl Microbiol. 2007;102(3):781-6.

44. Sapkota R, Knorr K, Jørgensen LN, O'Hanlon KA, Nicolaisen M. Host genotype is an important determinant of the cereal phyllosphere mycobiome. New Phytol. 2015;207(4):1134-44.

45. Yong T, Yang W, Xiang D, Zhu Z. Effect of wheat/maize/soybean and wheat/maize/sweet potato relay strip intercropping on bacterial community diversity of rhizosphere soil and nitrogen uptake of crops. Acta Agron Sin. 2012;38(02):333-43.

46. Zhou J, Deng Y, Luo F, He Z, Yang Y, Relman D. Phylogenetic molecular ecological network of soil microbial communities in response to elevated CO2. mBio. 2011;2(4):e00122-11.

47. Liang Y, Zhao H, Deng Y, Zhou J, Li G, Sun B. Long-term oil contamination alters the molecular ecological networks of soil microbial functional genes. Front Microbiol. 2016;7:60. 
48. Mougi A, Kondoh M. Diversity of interaction types and ecological community stability. Science (New York, NY). 2012;337(6092):349-51.

49. Feng K, Zhang Z, Cai W, Liu W, Xu M, Yin H, et al. Biodiversity and species competition regulate the resilience of microbial biofilm community. Mol Ecol. 2017;26(21):6170-82.

50. Shade A, Handelsman J. Beyond the Venn diagram: the hunt for a core microbiome. Environ Microbiol. 2012;14(1):4-12.

51. Wang F, Liang Y, Jiang Y, Yang Y, Xue K, Xiong J, et al. Planting increases the abundance and structure complexity of soil core functional genes relevant to carbon and nitrogen cycling. Sci Rep. 2015;5:14345.

52. Dunne JA, Williams RJ, Martinez ND. Network structure and biodiversity loss in food webs: robustness increases with connectance. Ecol Lett. 2002;5(4):558-67.

53. Eiler A, Heinrich F, Bertilsson S. Coherent dynamics and association networks among lake bacterioplankton taxa. ISME J. 2012;6(2):330-42.

54. Zhao H, Yu L, Yu M, Afzal M, Dai Z, Brookes P, et al. Nitrogen combined with biochar changed the feedback mechanism between soil nitrification and cd availability in an acidic soil. J Hazard Mater. 2020;390:121631.

55. Alguacil MM, Torrecillas E, García-Orenes F, Roldán A. Changes in the composition and diversity of AMF communities mediated by management practices in a Mediterranean soil are related with increases in soil biological activity. Soil Biol Biochem. 2014;76:34-44.

56. Zhang P, Chen X, Wei T, Yang Z, Jia Z, Yang B, et al. Effects of straw incorporation on the soil nutrient contents, enzyme activities, and crop yield in a semiarid region of China. Soil Tillage Res. 2016;160:65-72.

57. Kong X, Jin D, Tai X, Yu H, Duan G, Yan X, et al. Bioremediation of dibutyl phthalate in a simulated agricultural ecosystem by Gordonia sp. strain QH-11 and the microbial ecological effects in soil. Sci Total Environ. 2019;667:691-700.

58. Kong X, Jin D, Jin S, Wang Z, Yin H, Xu M, et al. Responses of bacterial community to dibutyl phthalate pollution in a soil-vegetable ecosystem. J Hazard Mater. 2018;353:142-50.

59. MagočT, Salzberg SL. FLASH: fast length adjustment of short reads to improve genome assemblies. Bioinformatics (Oxford, England). 2011:27(21):2957-63.

60. Edgar RC. UPARSE: highly accurate OTU sequences from microbial amplicon reads. Nat Methods. 2013;10(10):996-8.

61. Anderson MJ. A new method for non-parametric multivariate analysis of variance. Austral Ecol. 2001;26(1):32-46.

62. Caporaso JG, Kuczynski J, Stombaugh J, Bittinger K, Bushman FD, Costello EK, et al. Knight R.QIIME allows analysis of high-throughput community sequencing data. Nat Methods. 2010;7(5):335-6.

63. Zhou J, Deng Y, Luo F, He Z, Tu Q, Zhi X. Functional molecular ecological networks. mBio. 2010;1(4):e00169-10.

64. Deng Y, Jiang YH, Yang YF, He ZL, Luo F, Zhou JZ. Molecular ecological network analyses. BMC Bioinformatics. 2012;13(1):113.

\section{Publisher's Note}

Springer Nature remains neutral with regard to jurisdictional claims in published maps and institutional affiliations.

Ready to submit your research? Choose BMC and benefit from:

- fast, convenient online submission

- thorough peer review by experienced researchers in your field

- rapid publication on acceptance

- support for research data, including large and complex data types

- gold Open Access which fosters wider collaboration and increased citations

- maximum visibility for your research: over $100 \mathrm{M}$ website views per year

At BMC, research is always in progress.

Learn more biomedcentral.com/submissions 